\title{
Correlation of Personality Type with Student Interest in Sustainability in Civil Engineering
}

\section{Dr. Nicole Leo Braxtan, Manhattan College}

Dr. Nicole Leo Braxtan is currently an Assistant Professor in the Department of Civil and Environmental Engineering at Manhattan College. She received her Ph.D. from Lehigh University in Structural Engineering and her M.S. from Princeton University in Civil Engineering. In addition to her interest in engineering education, Dr. Braxtan specializes in the research area of structures in fire and fire protection of structural members.

\section{Dr. Goli Nossoni, Manhattan College}

Dr. Goli Nossoni is currently an Assistant Professor in the Department of Civil and Environmental Engineering at Manhattan College. She received her M.S. and Ph.D. from Michigan State University in Structural Engineering and Materials Science. In addition to her interest in engineering education, Dr. Nossoni specializes in the research area of materials especially concrete and corrosion of steel inside concrete. 


\title{
Correlation of Personality Type with Student Interest in Sustainability in Civil Engineering
}

\begin{abstract}
This paper presents a study on the relationships between personality type and student interest in sustainability within civil engineering. The personality types of undergraduate civil engineering students in a sophomore introduction to civil engineering course with sustainability-related topics were determined using the Myers Brigg Personality Type Indicator®. Sustainability related topics were presented in the course through traditional instructor-centered lectures. Personality type was then related to student-reported interest in civil engineering and sustainability, as well as student-reported importance of personal sustainability issues through surveys. Results correlate student interest ratings and importance ratings to personality type as well as gender. Results give preliminary insight into effective methods for attracting a more diverse population into civil engineering. Feeling $(\mathrm{F})$ and perceiving $(\mathrm{P})$ personality types atypical in civil engineering - showed largest increases in interest in sustainability at the end of the introductory civil engineering course. Female, thinking (T) personality type civil engineering students also showed an increase in civil engineering at the end of the introductory civil engineering course. Therefore sustainability may be a viable means for attracting atypical engineering personality types and females into civil engineering.
\end{abstract}

\section{Introduction}

Sustainability has been identified as a critical component in engineering education by the American Society of Civil Engineers (ASCE), the Accreditation Board for Engineering and Technology (ABET), and the National Academy of Engineering (NAE). ${ }^{1-3}$ Additionally, many Universities have incorporated sustainability concepts into civil engineering programs such as Carnegie Mellon University, Syracuse University, and Arizona State University, which have successfully implemented courses in sustainability in Civil Engineering freshman and sophomore courses. ${ }^{4-8}$ Sustainability in lower level civil engineering courses is often introduced at a conceptual level in the broad sense of environmental, economic, and social implications of engineered structures and materials as contrasted to the technical, physics-based course topics usually present in upper-level engineering courses.

There is an established knowledge base linking personality type with learning preferences in engineering curricula. ${ }^{9-15}$ In this vein, personality assessment can be a useful tool for improving the effectiveness of teaching technical engineering courses. As the topic of sustainability, particularly in its abstract introduction in lower level courses, may be fundamentally different from traditional technical engineering courses founded on scientific theory, it is useful to study the relationships between personality type and sustainability in engineering education.

\section{Myers Briggs Personality Type Indicator and Type Theory}

A variety of personality assessment tools are available and easily accessible, one of the most well-known being the Myers Brigg Personality Type Indicator ${ }^{\circledR}$ (MBTI). The MBTI identifies 16 different personality types founded on preferences in four major categories based on Jung's Theory of Psychological Types. MBTI results indicate whether a person tends to be extroverted (E) or introverted (I), sensing (S) or intuitive (N), thinking (T) or feeling (F), and judging (J) or perceiving $(\mathrm{P})$. Extroverted types focus energy on the outer world while introverted types focus 
energy on the inner world. Sensing types process information through actual facts and details that they encounter through their senses while intuitive types think more in abstract theory, general impressions, and intuition. Thinking types make decisions based on logical, impersonal facts while feeling types are subjective and value-based. Finally, judging types prefer orderly, structured, task-oriented lives while perceiving types prefer flexibility and openness.

Extensive research performed in the 1980s by the ASEE-MBTI Engineering Consortium of eight universities showed engineering students favor thinking and judging personality types and are more often introverted; there was little difference between sensing and intuitive types. ${ }^{9}$ Additional research also supports these findings. ${ }^{10-15}$

\section{Course and Survey Description}

This paper presents a study on the relationships between personality type and student-reported interest in civil engineering and sustainability within civil engineering. The paper also discusses personality type correlation with personal sustainability issues. The experimental group included sophomore civil engineering students in an introductory civil engineering course which includes sustainability related topics at Manhattan College during the fall semester of 2014. The course focused on traditional civil engineering topics and construction methods as well as sustainable buildings and construction. Students describe sustainable building rating systems, utilize traditional techniques for surveying, apply principles of passive design, explain and formulate preliminary designs of alternate energy systems, and describe behavior and construction methods of building materials. The course is taught in a traditional, instructor-led lecture format. Three sections of the course taught by two different faculty members were included in the study. 59 students were enrolled in the course, but useable survey data was only received by 38 students some students did not properly identify a personality type and/or did not complete the interest and importance questions. Students were asked to complete the personality indicator online outside of class time and then report the results on an in-class survey. Due to circumstances beyond the authors' control at the time, some students were unable or chose not to complete the online personality assessment and thus their interest rating and importance ratings could not be correlated to personality type. During future surveys and assessment, the students will complete the personality assessment in class along with the interest and importance surveys so that more complete data can be gathered.

The personality types of the undergraduate civil engineering students were determined using self-reported responses to the MBTI. Students then completed surveys which requested student personality type, student interest in sustainability, student interest in civil engineering, and importance of personal sustainability issues both before and after the course. Interest in sustainability and civil engineering was reported as: no interest, little interest, neither interest nor disinterest, considerable interest, or passion for sustainability/civil engineering. Personal sustainability related topics are shown in the survey excerpt in Table 1 and relate to decisions students may make on a daily basis which pertain to sustainability.

\section{Survey Results}

Survey results were formulated to consider an Interest Rating Score and an Importance Rating Score on a scale of 0 through 4 . The Interest Rating score was calculated for level of interest in both civil engineering and sustainability before and after the course as an average score where 
responses were quantified as follows: passion for civil engineering/sustainability $=4$ points; considerable interest in civil engineering/sustainability $=3$ points; neither interest nor disinterest civil engineering/sustainability $=2$ points; little interest civil engineering/sustainability $=1$ point; and no interest civil engineering/sustainability $=0$ points. Importance Rating score was calculated for the questions about degree of importance of several personal sustainability issues as quantified in the question statement (very important $=4$ points; important $=3$ points; neutral $=$ 2 points; unimportant $=1$ point; not important at all $=0$ points $)$.

Table 1: Survey excerpt for Personal Sustainability Issues

\begin{tabular}{|c|c|c|c|c|c|c|}
\hline & 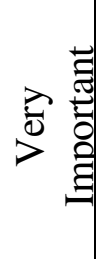 & 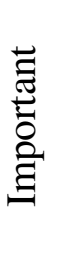 & $\begin{array}{l}\text { त्ञ } \\
\text { 苛 } \\
\text { Z }\end{array}$ & 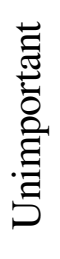 & 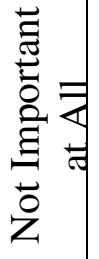 & 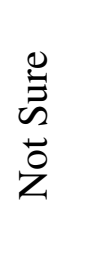 \\
\hline Recycling & 4 & 3 & 2 & 1 & 0 & N/A \\
\hline $\begin{array}{l}\text { Minimizing waste sent to the } \\
\text { landfill }\end{array}$ & 4 & 3 & 2 & 1 & 0 & N/A \\
\hline $\begin{array}{l}\text { Choosing food based on its } \\
\text { environmental impact }\end{array}$ & 4 & 3 & 2 & 1 & 0 & N/A \\
\hline Conserving water & 4 & 3 & 2 & 1 & 0 & N/A \\
\hline $\begin{array}{l}\text { Purchasing environmentally } \\
\text { friendly products }\end{array}$ & 4 & 3 & 2 & 1 & 0 & N/A \\
\hline Conserving energy & 4 & 3 & 2 & 1 & 0 & N/A \\
\hline $\begin{array}{l}\text { Minimizing carbon emissions } \\
\text { from transportation }\end{array}$ & 4 & 3 & 2 & 1 & 0 & N/A \\
\hline
\end{tabular}

Personality Distribution of Second Year Civil Engineering Students

Figure 1 shows the distribution of personality types determined through the MBTI surveys for the sophomore civil engineering students at Manhattan College. Each personality type is presented as a 4-letter abbreviation indicative of the four personality preferences. For example: ENTJ indicates an extroverted (E) - intuitive (N) - thinking (T) - judging (J) personality type. Data is also presented for the personality type distribution for civil engineering students as determined by the ASEE-MBTI Consortium. ${ }^{9}$ The most common personality types at Manhattan College were ESTJ (23\%), INTJ (20\%), and ISTJ (15\%). Previous data from the ASEE-MBTI consortium showed the most common personality types in civil engineering in were ISTJ (23\%) and ESTJ (21\%) with the next most popular personality type of ENTJ with only 7\%. ESTJ and ISTJ were dominant in both the current Manhattan College survey and the historical data from the ASEE-MBTI Consortium. INTJ personality type was dominant in the Manhattan College survey, but only comprised $4 \%$ of civil engineering students in the ASEE-MBTI Consortium data. It is noted that the Manhattan College survey includes only sophomore engineering students whereas the ASEE-MBTI Consortium data includes students of all years. A potential 
implication of this that there may have been students present at the sophomore level that select out of engineering by the junior year such that the two populations may not be entirely similar.

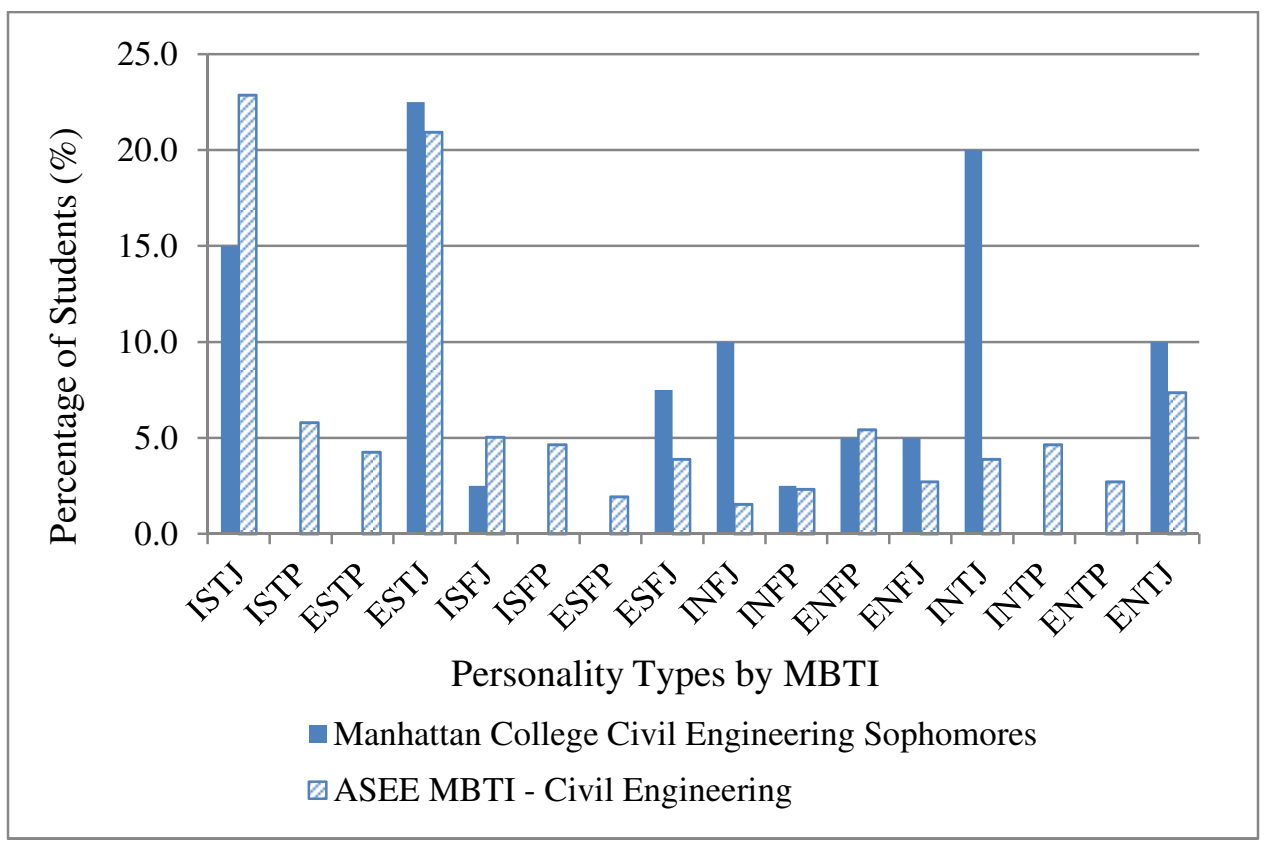

Figure 1: Personality Type Distribution Manhattan College Sophomore Civil Engineers Compared to ASEE-MBTI Consortium Data for Civil Engineering

Table 2 shows the comparison of the four main categories of personality traits - extravert (E) or introvert $(\mathrm{I})$, sensing $(\mathrm{S})$ or intuitive $(\mathrm{N})$, thinking $(\mathrm{T})$ or feeling $(\mathrm{F})$, and judging $(\mathrm{J})$ or perceiving $(\mathrm{P})$ for both Manhattan College sophomore civil engineers and the ASEE-MBTI Consortium civil engineers and all types of engineers. Although the ASEE survey was performed over 30 years ago, trends are still relevant and present today. In particular the strong tendency for engineering students toward the "TJ" personality types found in the previous survey is also present in the current survey data. Surveys indicated $71 \%$ of sophomore civil engineering students at Manhattan College were thinking (T) type, in close comparison with the previous results of $72 \%$ thinking in the ASEE-MBTI data. 93\% of Manhattan College sophomore civil engineering students indicated as judging $(\mathrm{J})$ type, an even greater dominance in civil engineering than the previous results of $68 \%$. There was an even split of preference between extrovert and introvert for civil engineering students at Manhattan College, a similar result when compared to the previous study with $49 \%$ extravert and $51 \%$ introvert. Finally, sophomore civil engineering students at Manhattan College showed a similar split between sensing (48\%) and intuitive (52\%) types. This is consistent with the previous data for all types of engineering (53\% Sensing) but lower than the percentage of sensing types $(69 \%)$ specifically in civil engineering.

\section{Interest Rating Scores for Civil Engineering and Sustainability}

Interest Ratings Scores for civil engineering and sustainability before and after the sophomore, introductory civil engineering course are shown in Table 3 for thinking/feeling and judging/perceiving personality types. Historically engineers have been associated with thinking 
and judging personality types and it is therefore of interest in this paper to study the typical ( $\mathrm{T}$ and/or J) vs. atypical ( $\mathrm{F}$ and/or $\mathrm{P}$ ) personality type in engineering. Increase in interest score is calculated as difference in score after and score before, divided by score before. Data for the perceiving personality types is useful, however only 3 students identified as perceiving giving this a very limited sample size. Additional work should be done to determine if trends are constant within a larger sample size.

Table 2: Personality Type Preferences in Sophomore Civil Engineering Students at Manhattan College Compared to ASEE-MBTI Consortium Data

\begin{tabular}{|c|c|c|c|}
\hline $\begin{array}{c}\text { Personality } \\
\text { Type } \\
\text { Preference }\end{array}$ & $\begin{array}{c}\text { Manhattan } \\
\text { College - } \\
\text { Civil } \\
\text { Engineering }\end{array}$ & $\begin{array}{c}\text { ASEE-MBTI } \\
\text { Consortium - } \\
\text { Civil } \\
\text { Engineering }\end{array}$ & $\begin{array}{c}\text { ASEE-MBTI } \\
\text { Consortium - } \\
\text { All } \\
\text { Engineering }\end{array}$ \\
\hline E & $50 \%$ & $49 \%$ & $33 \%$ \\
\hline I & $50 \%$ & $51 \%$ & $67 \%$ \\
\hline S & $48 \%$ & $69 \%$ & $53 \%$ \\
\hline $\mathrm{N}$ & $52 \%$ & $31 \%$ & $47 \%$ \\
\hline T & $71 \%$ & $72 \%$ & $74 \%$ \\
\hline F & $29 \%$ & $28 \%$ & $26 \%$ \\
\hline & & & \\
\hline $\mathrm{J}$ & $92 \%$ & $68 \%$ & $61 \%$ \\
\hline $\mathrm{P}$ & $8 \%$ & $32 \%$ & $39 \%$ \\
\hline
\end{tabular}

Table 3: Interest Rating Scores for Civil Engineering and Sustainability Before and After Course

\begin{tabular}{|c|c|c|c|c|c|c|c|}
\hline & & \multicolumn{3}{|c|}{ Civil Engineering } & \multicolumn{3}{c|}{ Sustainability } \\
\hline $\begin{array}{c}\text { Personality } \\
\text { Trait }\end{array}$ & $\begin{array}{c}\text { Sample } \\
\text { Size } \\
\text { (N) }\end{array}$ & $\begin{array}{c}\text { Before } \\
\text { Course }\end{array}$ & $\begin{array}{c}\text { After } \\
\text { Course }\end{array}$ & $\begin{array}{c}\% \\
\text { Increase } \\
\text { in Score }\end{array}$ & $\begin{array}{c}\text { Before } \\
\text { Course }\end{array}$ & $\begin{array}{c}\text { After } \\
\text { Course }\end{array}$ & $\begin{array}{c}\% \\
\text { Increase } \\
\text { in Score }\end{array}$ \\
\hline T & 27 & 3.04 & 3.11 & $2 \%$ & 2.74 & 3.04 & $11 \%$ \\
\hline F & 11 & 3.18 & 3.18 & $0 \%$ & 2.36 & 3.09 & $31 \%$ \\
\hline & & & & & & & \\
\hline J & 35 & 3.06 & 3.09 & $1 \%$ & 2.63 & 3.03 & $15 \%$ \\
\hline P & 3 & 3.33 & 3.33 & $0 \%$ & 2.67 & 3.33 & $25 \%$ \\
\hline
\end{tabular}

Students with $\mathrm{F}$ and P personality type preferences (atypical engineers) had larger increases in Interest Rating Scores for sustainability than their $\mathrm{T}$ and $\mathrm{J}$ counterparts (typical engineers). Feeling personality types tend to make decisions based more on the impact of their decisions on others and seek to maintain harmony. The basis of sustainability includes making decisions that mitigate harmful effects on future generations. As such, discussing sustainability related topics in civil engineering may be more appealing to feeling personality types than the logical, objective thinking types in engineering. Perceiving personality types are often more flexible and adaptive. It is possible that the perceiving type students were more open to learning new topics 
of sustainability in civil engineering, which are often broader and more holistic than the technical and physics based content typically found in engineering.

$\mathrm{T}$ and $\mathrm{J}$ personality types demonstrated smaller increases in Interest Rating Scores for sustainability. It is possible that their tough-minded, analytical nature was not as affected by the broader, conceptual discussions about sustainability. $\mathrm{F}$ and $\mathrm{P}$ personality type preferences are less common in civil engineering and this larger increase in Interest Rating Score for sustainability indicates that sustainability may be a viable way to attract atypical engineering personality types into civil engineering.

There was little or no increase in Interest Score for Civil Engineering for all personality types, however Interest Rating Scores were high to begin with. 92\% of students responded with "considerable interest" or "passion for" civil engineering before the class - this increased to $97 \%$ after the class. The students that were included in this study have already chosen civil engineering as a major, and would therefore be expected to have considerable interest in the topic.

Importance Rating Scores for Personal Sustainability Issues

Importance Rating Scores for personal sustainability issues reported by the sophomore students before and after the introductory course related to sustainability at Manhattan College are shown in Table 4. Percentage increase in score is again calculated based on the difference in score after and before, divided by the score before the course.

Table 4: Importance Rating Scores Before and After Course

\begin{tabular}{|c|c|c|c|c|}
\hline $\begin{array}{c}\text { Personality } \\
\text { Trait }\end{array}$ & $\begin{array}{c}\text { Sample Size } \\
(\mathrm{N})\end{array}$ & $\begin{array}{c}\text { Before } \\
\text { Course }\end{array}$ & $\begin{array}{c}\text { After } \\
\text { Course }\end{array}$ & $\begin{array}{c}\text { \% Increase } \\
\text { in Score }\end{array}$ \\
\hline $\mathrm{T}$ & 27 & 2.76 & 3.19 & $16 \%$ \\
\hline $\mathrm{F}$ & 11 & 2.51 & 3.10 & $24 \%$ \\
\hline & & & & \\
\hline $\mathrm{J}$ & 35 & 2.70 & 3.16 & $17 \%$ \\
\hline $\mathrm{P}$ & 3 & 2.48 & 3.14 & $27 \%$ \\
\hline
\end{tabular}

Again, the atypical engineering personality types of $\mathrm{F}$ and $\mathrm{P}$ showed greater increases in Importance Rating scores than their $\mathrm{T}$ and $\mathrm{J}$ typical engineering counterparts. The $\mathrm{F}$ and $\mathrm{P}$ personality types were more influenced on matters related to sustainability than the tough, analytic $\mathrm{T}$ and $\mathrm{J}$ personality types.

Gender Study

Interest Ratings Scores for civil engineering and sustainability before and after the course in this study are presented for female compared to male sophomore engineering students at Manhattan College. Data is presented here, however the sample size of female students was only 8, and thus additional work should be done to determine if trends are constant within a larger sample size. Judging and perceiving personality traits are not presented here for analysis as there were no perceiving type females present in the study. 
There was no increase in interest in civil engineering for male students before and after the course. There was an increase of $14 \%$ for female civil engineering students with respect to civil engineering. The introductory civil engineering course that the students were enrolled in framed civil engineering in a broader, more conceptual sense through the inclusion of sustainability. This type of framework may be more appealing to the female students.

There were larger increases in Interest Scores in sustainability for the F type personalities for both male and female civil engineering students. Interestingly, the male $\mathrm{F}$ type personalities showed a greater increase in interest in sustainability than the female $\mathrm{F}$ type personalities. The male $\mathrm{F}$ type personalities had the lowest rating of sustainability before the course and the highest rating after the course.

Table 5: Interest Rating Scores by Gender

\begin{tabular}{|c|c|c|c|c|c|c|c|c|}
\hline & & & \multicolumn{3}{|c|}{ Civil Engineering } & \multicolumn{3}{|c|}{ Sustainability } \\
\hline Gender & $\begin{array}{c}\text { Personality } \\
\text { Trait }\end{array}$ & $\begin{array}{c}\text { Sample } \\
\text { Size } \\
(\mathrm{N})\end{array}$ & $\begin{array}{c}\text { Before } \\
\text { Course }\end{array}$ & $\begin{array}{c}\text { After } \\
\text { Course }\end{array}$ & $\begin{array}{c}\% \\
\text { Increase } \\
\text { in Score }\end{array}$ & $\begin{array}{c}\text { Before } \\
\text { Course }\end{array}$ & $\begin{array}{c}\text { After } \\
\text { Course }\end{array}$ & $\begin{array}{c}\% \\
\text { Increase } \\
\text { in Score }\end{array}$ \\
\hline Female & $\mathrm{T}(63 \%)$ & 5 & 2.80 & 3.20 & $14 \%$ & 3.20 & 3.40 & $6 \%$ \\
\hline & $\mathrm{F}(37 \%)$ & 3 & 3.33 & 3.33 & $0 \%$ & 2.67 & 3.00 & $13 \%$ \\
\hline & & & & & & & & \\
\hline Male & $\mathrm{T}(73 \%)$ & 22 & 3.09 & 3.09 & $0 \%$ & 2.64 & 2.95 & $12 \%$ \\
\hline & $\mathrm{F}(27 \%)$ & 8 & 3.13 & 3.13 & $0 \%$ & 2.25 & 3.13 & $39 \%$ \\
\hline & & & & & & & & \\
\hline Female & All T and F & 8 & 3.00 & 3.25 & $8 \%$ & 3.00 & 3.25 & $8 \%$ \\
\hline Male & All T and F & 30 & 3.10 & 3.10 & $0 \%$ & 2.53 & 3.00 & $18 \%$ \\
\hline
\end{tabular}

Importance Rating Scores for personal sustainability issues for male and female civil engineers is shown in Table 6. Both female and male civil engineering students reported a larger increase in Importance Rating Scores for $\mathrm{F}$ type personalities compared to $\mathrm{T}$ type personalities. Female engineering students of any personality type had a greater increase in Importance Rating Score than their male counterparts. Again, the subjective feeling personality types were more influenced in their personal sustainability rankings than their analytic, thinking counterparts.

Table 6: Importance Rating Scores by Gender

\begin{tabular}{|c|c|c|c|c|c|}
\hline Gender & $\begin{array}{c}\text { Personality } \\
\text { Trait }\end{array}$ & $\begin{array}{c}\text { Sample } \\
\text { Size } \\
(\mathrm{N})\end{array}$ & $\begin{array}{c}\text { Before } \\
\text { Course }\end{array}$ & $\begin{array}{c}\text { After } \\
\text { Course }\end{array}$ & $\begin{array}{c}\% \\
\text { Increase } \\
\text { in Score }\end{array}$ \\
\hline Female & $\mathrm{T}$ & 5 & 2.97 & 3.57 & $20 \%$ \\
\hline & $\mathrm{F}$ & 3 & 2.10 & 2.80 & $34 \%$ \\
\hline & & & & & \\
\hline Male & $\mathrm{T}$ & 22 & 2.71 & 3.10 & $14 \%$ \\
\hline & $\mathrm{F}$ & 8 & 2.66 & 3.21 & $21 \%$ \\
\hline & & & & & \\
\hline Female & All T and F & 8 & 2.64 & 3.29 & $25 \%$ \\
\hline Male & All T and F & 30 & 2.70 & 3.13 & $16 \%$ \\
\hline
\end{tabular}




\section{Conclusions}

Results from surveys correlating personality type with interest in sustainability in civil engineering indicate atypical feeling and perceiving personality types express greater increases in interest in sustainability and personal sustainability-related issues. This finding supports the theory that sustainability may hold promise to attracting atypical personality types into civil engineering.

Female civil engineering students with thinking type personalities showed an increase in interest in civil engineering after an introductory civil engineering course with sustainability related topics, whereas other personality types maintained "considerable" interest in civil engineering at the end of the course. Framing an introductory civil engineering course around sustainability may hold promise to increase female student interest in civil engineering. It is important to continue this study and increase the sample size to determine if this trend continues.

Male civil engineering students in this study with feeling type personalities showed a larger increase in interest in sustainability at the end of an introductory civil engineering course with sustainability related topics. This result indicates that sustainability may be a viable way to attract atypical male engineering types into civil engineering.

\section{Acknowledgments}

The authors are grateful to Dr. Qian Wang for distributing the end of course surveys to the students in his section of the course and sharing this additional data with the authors.

\section{References}

1. American Society of Civil Engineering (ASCE) (2008). Civil Engineering Body of Knowledge for the 21st Century. Reston, Virginia: ASCE.ABET

2. Accreditation Board for Engineering Technology, Inc, (ABET) (2010). "Criteria for Accrediting Engineering Programs: Effective for Evaluations During the 2010-2011 Accreditation Cycles."

3. National Academy of Engineering (NAE-2008). Grand Challenges for Engineering, NAE, Washington, DC.

4. Davidson, C. I., Hendrickson, C. T., and Matthews, H. S. (2007) "Sustainable Engineering: A Sequence of Courses at Carnegie Mellon." International Journal of Engineering Education, 287-293.

5. Huntzinger, D. N., Hutchins, M. J., Gierke, J. S., and Sutherland, J. W. "Enabling Sustainable Thinking in Undergraduate Engineering Education.” International Journal of Engineering Education, 23(2) 2007: 218230.

6. Chau, K. W. "Incorporation of Sustainability Concepts into a Civil Engineering Curriculum." Journal of Professional Issues in Engineering Education and Practice, ASCE, 2007: 188-191.

7. El-Zein, A., Airey, D., Bowden, P., and Clarkeburn, H. "Development of a Course on Environmental Sustainability, Ethical Decision-making and Communication Skills in Engineering." International Conference on Engineering Education, September 2007.

8. Center of Sustainable Engineering, "Adding Sustainability to Engineering Education Workshop." Oral communication, Syracuse University, May 2011.

9. McCaulley, M.H. et al. 1983. Applications of psychological type in engineering education. Engineering Education : 394-400.

10. Felder, R.M. et al. 1993. A longitudinal study of engineering student performance and retention I. Success and failure in the introductory course. Journal of Engineering Education : 15-21. 
11. McCaulley, M.H. et al. 1987. Myers-Briggs Type Indicator and retention in engineering. International Journal of Applied Engineering Education 3(2): 99-109.

12. Rosati, P. 1997. Psychological types of Canadian engineering students. Journal of Psychological Type 41: 33-37.

13. Scott, T.H. \& Scott, J.C. 1996. Utilization of the Myers-Briggs Type Indicator by a freshman engineering advising center. In Lifelong Learning in Engineering Proceedings, American Society for Engineering Education 1996 Southeastern Section Meeting : April 14-16, 1996, Knoxville, Tennessee. Washington, D.C.: ASEE.

14. Staiger, E.H. 1990. Electrical engineering freshman type tables. Journal of Psychological Type 20: 40-45

15. Thomas, A. et al. 2000. The evidence remains stable: the MBTI predicts attraction and attrition in an engineering program. Journal of Psychological Type 55: 35-42. 